\title{
An Examination of the Development of the Construction and Demolition Waste-Related Regulations in Turkey
}

\author{
Burcu Salgı ${ }^{1 *}$ \\ 1 Department of Architecture, Faculty of Architecture, Erciyes University, 38039 Kayseri, Turkey \\ ${ }^{*}$ Corresponding author, e-mail: bsalgin@gmail.com
}

Received: 26 May 2019, Accepted: 02 July 2019, Published online: 23 September 2019

\begin{abstract}
In order to manage construction and demolition (C\&D) waste, which is harmful to the natural environment and human health, legislation has been introduced throughout the world. In Turkey, the most comprehensive regulation that deals only with C\&D waste management (WM), entered into force in 2004. However, changes in the construction sector from 2004 until the present has led to inadequacies in some areas of this regulation. Therefore, a new draft regulation was prepared in 2017. This study is conducted to understand the strengths and weaknesses of the C\&D WM regulations, identify the problems, and give recommendations. A threestage methodology is adopted that includes a literature review, classifying the findings and analysing the relevant literature under the five main topics (the objective and the extent of the regulations, occupational health and safety issues, planning the demolition, collecting and transporting the produced waste, and establishing and operating the recovery plants). The findings show that the draft regulation contains arrangements for Turkey's current conditions. The terms of the draft regulation have brought more importance to environmental and human health, and occupational health and safety issues. However, only asbestos has been highlighted in the draft regulation as a hazardous waste. The draft regulation includes a limited arrangement regarding the waste produced in the case of refurbishment projects. It is assumed that eliminating the deficiencies in the draft regulation and the enactment of it will be an important step. Thus, environmental and economic benefits for Turkey will follow.
\end{abstract}

Keywords

C\&D waste, legislation, Turkey

\section{Introduction}

In parallel with construction sector activities, new buildings are constructed rapidly. Refurbishments are carried out according to improvements in the construction sector, the changing demands of the users or the age of the buildings. In addition, in many countries, several buildings are demolished within the scope of urban transformation projects. All these activities have put C\&D WM issues on countries' agendas. In the European Union (EU), C\&D waste was the single largest waste stream, accounting for $36.4 \%$ of all waste in 2016, 2538 million tons in total (EUROSTAT, 2019). In the UK, 66.2 million tons of non-hazardous C\&D waste generation was reported in 2016 (DEFRA, 2019). In the USA, an analysis was performed to estimate the total amount of C\&D waste generation, resulting in an estimated total of 583 million tons of C\&D waste generation for 2014 (Townsend and Anshassi, 2018). Similar amounts of waste generation were reported in Hong Kong (EPD, 2018), and China (Wang et al., 2008). Since these large amounts of C\&D waste are considered to be an important environmental problem in many countries, many regulations on these issues have been introduced. C\&D WM is adopted as part of government policy, and guidelines regarding the issues have been prepared.

In the EU countries, directives relevant to C\&D WM are listed as the following: Waste Directive 2008, Landfill Directive, Integrated Pollution Prevention and Control Directive, Packaging and Packaging Waste and the Hazardous Waste Directive. The European Commission also prepared and published "EU Construction \& Demolition Waste Management Protocol and Guidelines" in 2018. In the USA, The Resource Conservation and Recovery Act (RCRA) governs the federal solid waste management system. According to RCRA, C\&D waste is 
a solid waste and can potentially be a hazardous waste. If a $C \& D$ waste stream does not contain asbestos and is not hazardous waste, management requirements are not covered by federal regulations. Since every State has the freedom to create $\mathrm{C} \& \mathrm{D} \mathrm{WM}$ regulations to fit their unique situations, there are several regulations in the USA (Clark et al., 2006). In the People's Republic of China (PRC), the government has not prepared specific laws for C\&D WM, but related provisions are covered by subordinate laws, including the Environmental Protection Law, the Cleaner Production Promotion Law, the Solid Waste Pollution Prevention Law, the Circular Economy Promotion Law and the Building Law. However, there are sixteen C\&D waste recycling-related standards and eight local standards in the PRC (AECOM, 2018). In Japan, C\&D waste source-separation and recycling requirements are mandatory. Since the Construction Material Recycling Law was enacted in May 2000 (AECOM, 2018), Japan's recycling rate has subsequently reached $96 \%$ by 2012 (MLIT, 2018).

Like many developing or developed countries, various legislation has been referred partly or wholly to C\&D waste issues in Turkey since the 1950s. The most comprehensive regulation in Turkey regarding the control and recovery of C\&D waste is the "Regulation of the Control of Excavation Soil, and Construction and Demolition Waste" number 25406, enacted by the Ministry of the Environment and Forestry, which came into force on March 18th, 2004. This regulation includes general rules about administrative and technical subjects on the reduction, collection, temporary storage, recovery, evaluation and disposal of excavation soil and C\&D waste. Although Turkey has a specific regulation designed for $\mathrm{C} \& \mathrm{D}$ waste, it is stated in some studies that there are some deficiencies in the content of the regulation because of changing conditions in construction sector activities in Turkey (Coşgun and Esin, 2006; Salgin, 2009). Since Turkey is a developing country, there is significant activity in the construction sector, and the role of the sector within the whole economy has drastically increased. The need for construction has also multiplied and gained urgency following the 1999 earthquakes (Akıner and Akıner, 2009).

Moreover, the government has begun a major urban renewal programme, aimed at readying Istanbul and other cities for future earthquakes (Oxford Business Group, 2018), as $66 \%$ of Turkey's land is in first and second level earthquake zones, which supports nearly $71 \%$ of the country's population. When the existing building stock of Turkey is considered, it is clear that the majority of the housing stock must be transformed through demolition, retrofitting and reinforcement activities (Deloitte Turkey, 2018). Thus, all these activities will increase $C \& D$ waste, and the need for efficient waste stream management will be increasingly important. For these reasons, a new draft regulation has been prepared, and efforts have been made to overcome the deficiencies of the previous regulation.

The goal of this study is to conduct an overview of C\&D WM regulations in Turkey to understand the strengths and weaknesses of the current and draft C\&D WM regulations; identify potential problems; produce an output that is useful for the country's regulatory framework for $\mathrm{C} \& \mathrm{D} \mathrm{WM}$ in the future, and develop recommendations. Determining the strengths and weaknesses of the regulations and developing recommendations for the elimination of deficiencies in the regulations is important in raising the level of awareness among rule makers, decision-makers and construction sector professionals.

In accordance with this goal, this study presents an overview of the improvements in C\&D WM regulations in Turkey. Since the 2004 regulation and the 2017 draft regulation are the most comprehensive, and the most recent regulations in this area, they are compared to each other. The deficiencies in the 2004 regulation and the arrangements for correcting them have been put forward. The improvements are discussed, and recommendations made.

\section{Methodology}

The focus of the study is to review the C\&D WM regulations in Turkey. To understand the strengths and weaknesses of the C\&D WM regulations, recognise the problems, and provide recommendations, a three-stage methodology is adopted. A literature review is included that classifies the findings and analyses the relevant literature.

Stage 1 involves conducting a literature review. Turkish WM legislations for $C \& D$ waste were acquired from the official website of the Official Gazette of the Republic of Turkey and the Ministry of the Environment and Urbanization. The keywords used for the search were as follows: C\&D WM regulations and WM regulations in Turkey. These laws and regulations that are partly or wholly related to C\&D WM issues in Turkey are respectively shown in Fig. 1.

Stage 2 is based on the classification of the findings. Content analysis was conducted on the results to determine the most relevant legislation regarding $C \& D$ waste. Until "Regulation of the Control of Excavation Soil, and Construction and Demolition Waste", C\&D WM issues were briefly addressed in the regulations (Official Gazette 


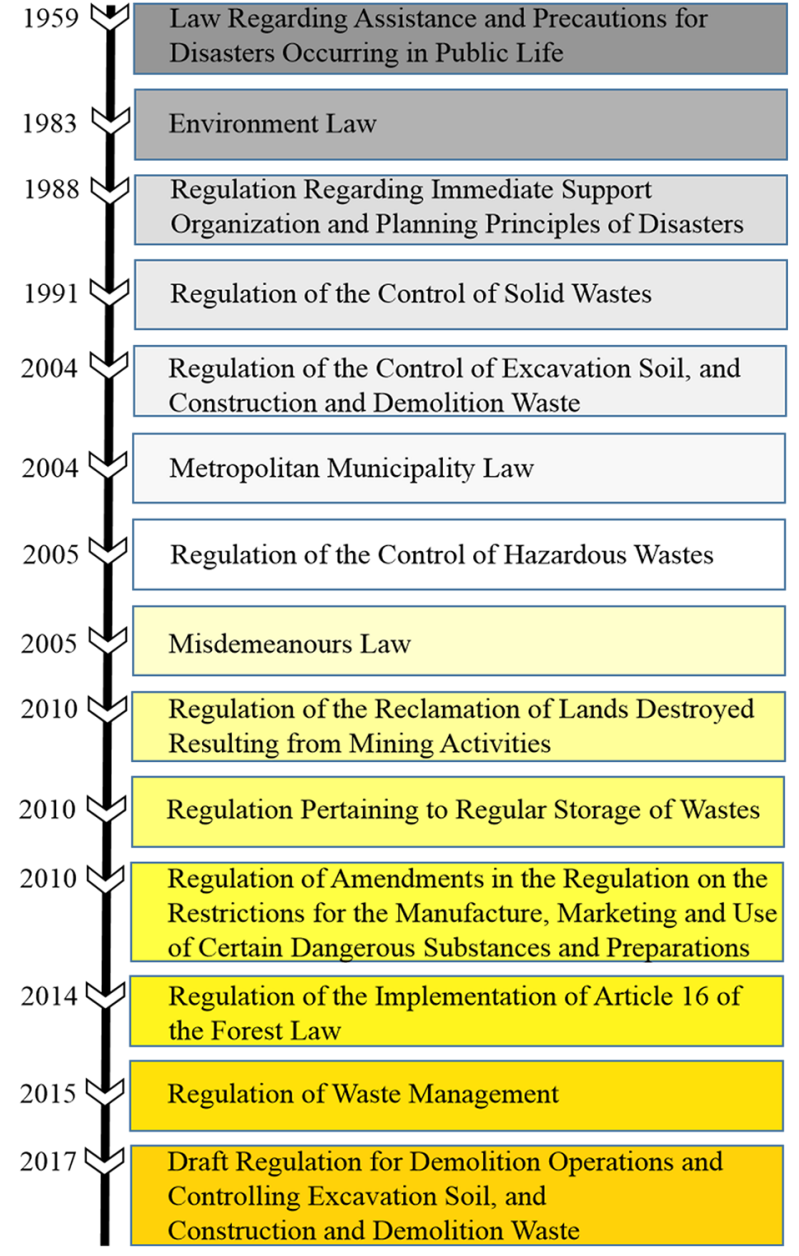

Fig. 1 Timeline of the C\&D waste-related regulations in Turkey

of the Republic of Turkey, 1959; 1983; 1988; 1991). Of all the regulations, it is found that "Regulation of the Control of Excavation Soil, and Construction and Demolition Waste" and "Draft Regulation for Demolition Operations and Controlling Excavation Soil, and Construction and Demolition Waste" are the most comprehensive and recent regulations entirely concerning $\mathrm{C} \& \mathrm{D}$ waste, and are examined in this study.

Stage 3 involves an analysis of the relevant literature. Based on the analysis of the most comprehensive and recent regulations concerning entirely $C \& D$ waste in Turkey, the comparison of the two regulations is discussed in subcategories. To determine these subcategories, the priorities in WM are clarified. Given that Turkey is a developing country, and because construction sector conditions change, so do the objectives and extent of the regulation. The number of urban regeneration projects is increasing rapidly, mainly due to reasons such as earthquake risk and aging buildings. A large amount of $C \& D$ waste is being produced as a result of urban transformation projects (Salgın and Coşgun, 2018). To cope with the huge amounts of waste, it is important to plan demolitions, collect and transport the produced waste, and establish recovery plants. Moreover, health and safety issues in the regulations have become important since C\&D waste may contain hazardous content such as asbestos. Accordingly, the regulations are examined based on the following subcategories: describing the objective and the extent of the regulations; studying the occupational health and safety issues in the regulations; planning the demolition; collecting and transporting the produced waste, and establishing and operating the recovery plants. From this, improving the C\&D WM regulations is discussed, deficiencies highlighted, and recommendations made for further studies.

\section{Results}

\subsection{Improvements to the C\&D WM Regulations in Turkey}

In Turkey, C\&D waste issue has entered the country's agenda with Article 4 of the "Law Regarding Assistance and Precautions for Disasters Occurring in Public Life". It is stated that the responsible persons should be determined by the governorships in order to clear the demolition waste after natural disasters (Official Gazette of the Republic of Turkey, 1959). The same issue is addressed by Article 14/b, 24/b, 24/c and 25 of the "Regulation Regarding Immediate Support Organization and Planning Principles of Disasters" (Official Gazette of the Republic of Turkey, 1988). It was prohibited to dump excavation soil to seas, lakes and rivers with Article 23 of the "Regulation of the Control of Solid Wastes" (Official Gazette of the Republic of Turkey, 1991). Similarly, C\&D WM issues are briefly addressed in several articles on the regulations, which are shown in Fig. 1 (Official Gazette of the Republic of Turkey, 1983; 2004b; 2005a; 2005b; 2010a; 2010b; 2010c; 2014; 2015).

There were no arrangements addressing Istanbul regarding the management of C\&D waste until 2002; however, the governorship of Istanbul put into force "The Directive for Controlling Excavation Soil and Construction Debris" with the purpose of preventing illegal dumping of C\&D waste at the sides of streams and roads, and especially determining the sites that could be used for landfill. Unfortunately, illegal dumping by streams and roadsides could not be prevented due to the deficiencies in the directive, and the need emerged for a new regulation (Birpınar and Akdağ Sar1, 2011). To this end, the "Regulation of the Control of Excavation Soil, and Construction and Demolition Waste" was published on March 18, 2004, as the first and most 
inclusive regulation focusing only on $\mathrm{C} \& \mathrm{D}$ waste. This regulation controls the general rules to be followed in addition to the technical and administrative issues regarding the initial reduction at source, collection, transportation, temporary storage, utilisation and disposal of C\&D waste with no harm caused to the environment. However, the developments and changes occurring in the Turkish construction sector since 2004 have further revealed the deficiencies of the regulation. In particular, the large amount of C\&D waste produced by the growing urban transformation projects has become a major problem for Turkey.

For this reason, it was necessary to update the regulation that was prepared in 2004. To this purpose, the "Regulation for Demolition Operations and Controlling Excavation Soil, and Construction and Demolition Waste" was published as a draft by the Ministry of the Environment and Urbanization on 21 April 2017. This draft regulation regulates the rules and procedures related to the management and control of demolition and excavation operations as well as the excavation soil and $C \& D$ waste produced by these operations, with no harm to the environment or human health and safety.

The revisions that were made to the draft regulation to eliminate the deficiencies in the regulation, prepared in 2004, were analysed under the following titles:

- Describing the objectives and extent,

- Studying occupational health and safety,

- Planning the demolition,

- Collecting and transporting the produced waste,

- Establishment and operation of recovery plants.

\subsection{Describing the objective and the extent}

A comparison of the two regulations showed that the description of the objective had changed. While the 2004 regulation was focused on "the rules that must be followed in the WM stages of excavation soil and C\&D waste in a way that does no harm to the environment" (Official Gazette of the Republic of Turkey, 2004a), the regulation that was prepared in 2017 was focused on "the principles of the management and control of the excavation soil and $\mathrm{C} \& \mathrm{D}$ waste that is produced by demolition and excavation operations in a way that does no harm to the safety of the environment and human health" (Republic of Turkey Ministry of the Environment and Urbanization, 2017). The phrase "demolition and excavation operations" in the target description of the 2017 draft shows that the extent of the regulation became broader, with the phrase "the safety of the environment and human health" indicating that more importance was attached to the relationship between human health and the $\mathrm{C} \& \mathrm{D}$ waste.

The extent of the draft regulation was also changed. While the 2004 regulation addressed "the principles related to the individual collection, temporary storage, transportation, recovery, utilization and disposal of excavation soil and C\&D waste in their production site" (Official Gazette of the Republic of Turkey, 2004a), the 2017 draft focuses on "the principles of the safety precautions to be taken during the demolition operation to protect the environment and human health, and demolition methods, as well as the individual collection, temporary storage, transportation, recovery, reuse, utilization and disposal of excavation soil and C\&D waste in the production site" (Republic of Turkey Ministry of the Environment and Urbanization, 2017). Based on this point, it was observed that the draft regulation attaches more importance to occupational health and safety, and includes the demolition methods that have improved with technological developments.

\subsection{Studying occupational health and safety}

While the 2004 regulation involves the principles to be followed in the demolition, dismantling and refurbishment of the buildings made using asbestos with the purpose of protecting the health and safety of workers (Official Gazette of the Republic of Turkey, 2004a), the 2017 draft includes an article introducing the obligation to use personal protective equipment and take all precautions required for occupational health and safety, as well as complying with the terms related to "notice about the training programs on asbestos handling" (Republic of Turkey Ministry of the Environment and Urbanization, 2017). This occurred as a result of an asbestos problem that emerged after the increase in demolition operations required by urban transformation projects. Even though the use of asbestos in Turkey was controlled from 2008 and banned with a regulation that was enacted by the Council of Ministers on December 2010, there are products containing asbestos in many buildings up to that date (Tuna Taygun, 2016). Asbestos fibres that hang in the air during the unsupervised dismantling of these products reach the lungs, and the fibres accumulate in lung tissue, leading to a variety of asbestos-related health problems over time. Thus, it is important that the demolition of asbestos products and the other hazardous waste during urban transformation processes be performed under supervision in accordance with these obligations (Salgin and Coşgun, 2018). With this article in the draft regulation, the level of awareness of hazardous C\&D waste has increased. 
Another article in the regulation is the condition about having an urgent medical team in attendance and a fire fighting team in the districts where controlled explosive demolition operations are performed (Republic of Turkey Ministry of the Environment and Urbanization, 2017). This new article shows that occupational health and safety issues have become more important in Turkey.

\subsection{Planning the demolition}

The issue of planning the buildings' demolition was not included in the 2004 regulation. However, it is mentioned comprehensively in the draft regulation. Accordingly, it is necessary to create a plan before demolition (Fig. 2). This plan needs to include the following topics:

- a map, a photo and a satellite image of the building, the function of the building, the number of floors, construction area and information about the building materials;

- the demolition method;

- an evaluation of the risks that might be created by the demolition on the surrounding buildings;

- emergency precautions;

- a work schedule; and

- a management plan for the waste to be produced (Republic of Turkey Ministry of the Environment and Urbanization, 2017).

It is compulsory that this plan is approved by the relevant authority. Since the most important strategy in the prevention/reduction of C\&D waste is managing this process within the framework of a plan, the comprehensive discussion of creating a demolition plan in the draft regulation has been determined to be positive regarding the

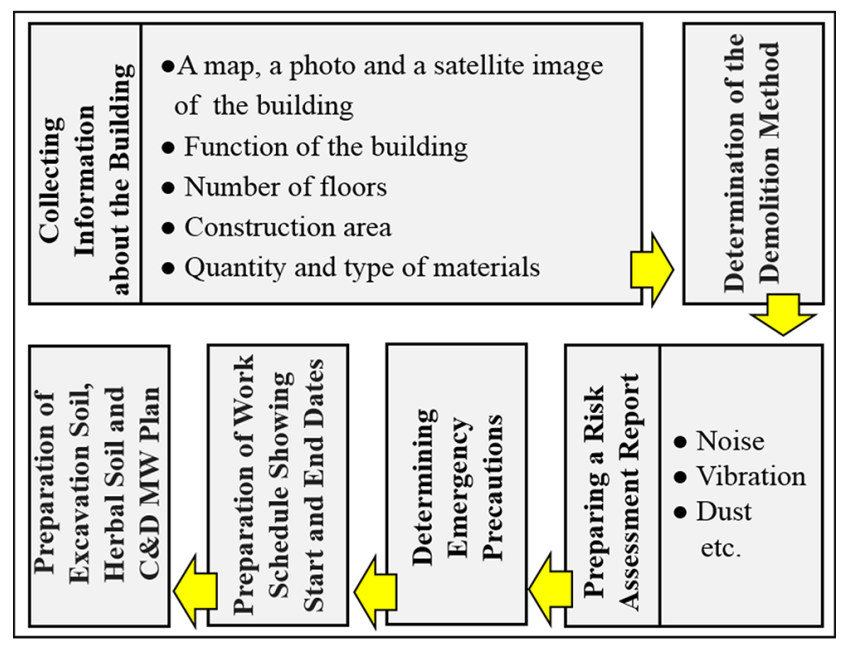

Fig. 2 The flow chart for demolition plan preparation reduction of the quantity and hazards of the C\&D waste to be produced.

The draft regulation also embraces the demolition methods in detail, which is consistent with the technological developments that have been made since 2004. The 2004 regulation did not mention any method in a detailed way except for the phrase "in cases that it is performed by construction equipment with hydraulics, the concrete structures including columns and beams are to be cut or destroyed" (Official Gazette of the Republic of Turkey, 2004a). However, the 2017 draft stated that the demolition operations would be performed using controlled explosive demolition methods, demolition methods with longreach demolition machines, excavator demolition methods or top-down demolition methods (Republic of Turkey Ministry of the Environment and Urbanization, 2017).

Another important development related to demolition operations was in selective demolition. The $2017 \mathrm{draft}$ made it compulsory to reuse the materials with selective demolition and to sort out the wastes at their source and subject them to recovery operations for the creation of an effective recovery and disposal system (Fig. 3) (Republic of Turkey Ministry of the Environment and Urbanization, 2017).

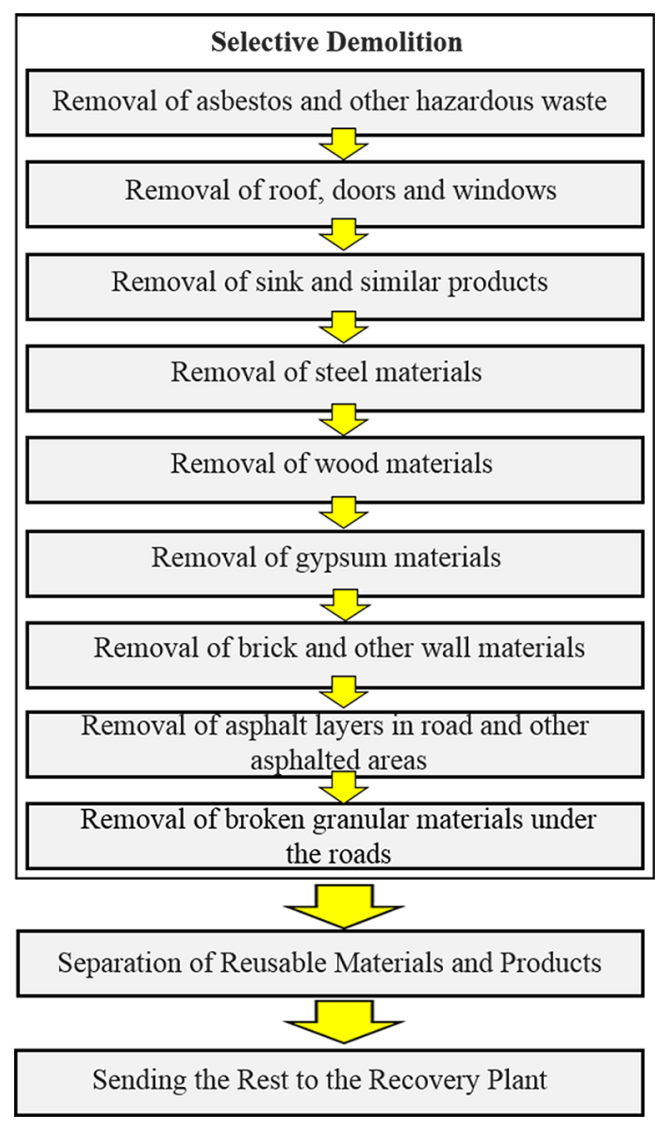

Fig. 3 The flow chart for selective demolition 
The purpose of selective demolition in the 2004 regulation was only to sort out the foreign substances that are not possible to recover before or during the demolition of buildings, and to perform the demolition on certain scales in a controlled manner (Official Gazette of the Republic of Turkey, 2004a). It is clear that the importance attributed to the reuse and recycling of waste increased with this approach in the $2017 \mathrm{draft}$.

\subsection{Collecting and transporting the produced waste}

Regarding the collection and transportation of the produced waste, the 2004 regulation mentions that the waste should be carried by vehicles with transportation licenses to the storage sites that have the necessary permissions (Official Gazette of the Republic of Turkey, 2004a). However, since 2004, it has been observed that this permission is not enough. It has not been possible to prevent illegal dumping because there was no technology to record the waste and track it from the production area to the place it is being transported. In the $2017 \mathrm{draft}$, as a result of developments in technology, a vehicle tracking system was created to solve this problem. The trucks collecting excavation soil and C\&D waste should be painted in yellow, have "vehicle to transport excavation soil and C\&D waste" written on them in capital letters, and the vehicles should have a vehicle tracking system installed in them (Republic of Turkey Ministry of the Environment and Urbanization, 2017). Therefore, it is possible to record collection and transportation operations. It is assumed that these methods will prevent illegal dumping.

\subsection{Establishment and operation of recovery plants}

The conditions for the establishment and the general qualities of recovery plants are mainly the same in the two regulations. However, the draft regulation makes it compulsory to surround the plant with at least a two-meter-high wire fence to prevent it from being seen from the outside, and to keep the plant clean and well maintained, while the 2004 regulation mentions surrounding the plant with wire fence (Official Gazette of the Republic of Turkey, 2004a; Republic of Turkey Ministry of the Environment and Urbanization, 2017). This situation can be accepted as an indicator of the increase in environmental awareness in Turkey.

According to the 2004 regulation, the aggregate products that have been recovered after processing in these plants are used in landfill operations (Official Gazette of the Republic of Turkey, 2004a). The 2017 draft comprehensively discusses the areas of usage for recovered aggregate products. These products can be used as landfill or foundation material, or as a component to produce concrete of different levels of strength. The regulation also includes the issue of sending wastes like glass, metal, wood, gypsum board, ceramic, brick, tile and plastic to recycling plants (Republic of Turkey Ministry of the Environment and Urbanization, 2017). Recycling of waste will reduce the use of raw materials and provide environmental and economic benefits.

The 2017 draft also suggests that analyses showing the qualities of the waste brought to recycling plants, as well as the qualities of the recycled products, should be conducted in laboratories established in the plants or in laboratories that have the necessary authority from the ministry (Republic of Turkey Ministry of the Environment and Urbanization, 2017). Thus, it will be possible to prevent the production of non-standardized products.

\section{Discussion}

Section three analyses the innovations offered by the 2017 draft regulation, which was prepared to eliminate the deficiencies in the 2004 regulation written to address the management of C\&D waste (Fig. 4).

It can be seen that the terms of the draft regulation have brought more importance to environmental and human health, and occupational health and safety issues in Turkey.

\begin{tabular}{|l|l|}
\hline Subcategories & Improvements \\
\hline $\begin{array}{l}\text { Describing the } \\
\text { Objective } \\
\text { and the Extent }\end{array}$ & $\begin{array}{l}\text { The objective was changed and broadened } \\
\text { The extent was changed and broadened }\end{array}$ \\
\hline $\begin{array}{l}\text { Studying } \\
\text { Occupational } \\
\text { Health and Safety }\end{array}$ & $\begin{array}{l}\text { The level of awareness of hazardous C\&D } \\
\text { waste was increased } \\
\text { The importance of occupational health and } \\
\text { safety issues were increased }\end{array}$ \\
\hline $\begin{array}{l}\text { Planning the } \\
\text { Demolition }\end{array}$ & $\begin{array}{l}\text { The issue of planning the buildings' demolition } \\
\text { was included } \\
\text { The demolition methods were discussed in } \\
\text { detail } \\
\text { The importance attributed to the reuse and } \\
\text { recycling of waste increased with selective } \\
\text { demolition }\end{array}$ \\
\hline $\begin{array}{l}\text { Collecting and } \\
\text { Transporting the } \\
\text { Produced Waste }\end{array}$ & $\begin{array}{l}\text { A vehicle tracking system was created to record } \\
\text { collection and transportation operations }\end{array}$ \\
\hline $\begin{array}{l}\text { Establishment } \\
\text { and Operation of } \\
\text { Recovery Plants }\end{array}$ & \begin{tabular}{l} 
- $\begin{array}{l}\text { The areas of usage for recovered aggregate } \\
\text { were discussed in detail } \\
\text { Kinds of wastes send to recycling plants were } \\
\text { discussed in detail } \\
\text { The necessity of requesting for waste and } \\
\text { recycled product analyses from authorized } \\
\text { laboratories was introduced }\end{array}$ \\
\hline
\end{tabular} \\
\hline
\end{tabular}

Fig. 4 Improvements from the 2004 regulation to the $2017 \mathrm{draft}$ regulation 
This regulation embraces the points below to solve the problem of increasing waste, especially after the growth in demolition operations on urban transformation sites:

- Determining the demolition methods and planning the demolition operations;

- Recording the waste during collection and transportation; and

- Caring about recovery and making selective demolition compulsory.

However, it is believed that the terms of the draft regulation have certain deficiencies as well. The draft regulation stresses that asbestos is a hazardous waste that creates a risk for human and environmental health in building demolition operations. Some hazardous chemicals, including polychlorinated biphenyls (PCBs), lead and mercury also create risks for human and environmental health. In this regard, it is recommended that all of these hazardous wastes should be discussed in detail within the scope of the regulation; the buildings should be analysed for these wastes, and the demolition operations should be performed taking precautions in accordance with the results.

The draft regulation includes a limited arrangement about the waste to be produced in the case of refurbishment during the usage stage of the buildings. Waste producers are responsible for applying to the relevant authority - or the companies that have obtained licenses for the collection and transportation of the waste - to have the waste collected, transported, and be taken to the permitted sites for C\&D waste up to two tons (Republic of Turkey Ministry of the Environment and Urbanization, 2017). However, it is believed that this arrangement is not enough for the management of the C\&D waste to be produced by refurbishment operations. It is important to prepare a refurbishment plan (Fig. 5) before every refurbishment in the same way that the demolition plans are prepared for building demolition operations.

\begin{tabular}{|c|c|c|c|c|c|c|}
\hline \multirow{4}{*}{ 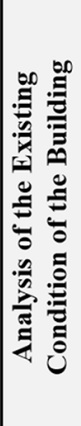 } & \multirow{4}{*}{$\begin{array}{l}\text { - Structural } \\
\text { System } \\
\text { - Materials } \\
\text { and Products }\end{array}$} & \multirow{4}{*}{$\checkmark$} & \multirow{4}{*}{ 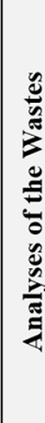 } & $\begin{array}{c}\text { Determining } \\
\text { Type and Quantity } \\
\text { of Waste }\end{array}$ & & \multirow{4}{*}{ 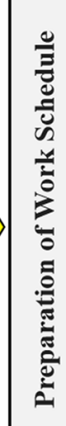 } \\
\hline & & & & $\begin{array}{l}\text { Determining What } \\
\text { to Do with Wastes }\end{array}$ & & \\
\hline & & & & 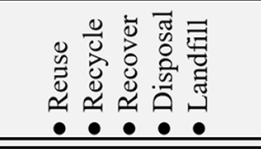 & & \\
\hline & & & & $\begin{array}{c}\text { Determining Waste } \\
\text { Plants }\end{array}$ & & \\
\hline
\end{tabular}

Fig. 5 The flow chart of the refurbishment plan proposal
In this plan, it is necessary to analyse the building in terms of structural systems, materials and products, and hazardous content. Following this, the types and amounts of waste to be produced should be identified, and the reuse, recycling and recovery possibilities should be determined, with the related plants specified accordingly. A work schedule should also be included in the plan to consider the people living nearby who will be exposed to noise and dust. The work schedule should contain the start and end dates and the working hours. It is believed that there is also a need to arrange to register the refurbishment plan with the relevant administration and include the necessary information and permissions.

\section{Conclusion}

C\&D WM issues in Turkey have been discussed under various legislation since the 1950s. The most comprehensive regulation was produced in 2004 called the "Regulation of the Control of Excavation Soil, and Construction and Demolition Waste" enacted by the Ministry of the Environment and Forestry. However, considering the changing country conditions within the fifteen years that have passed since the publication of this regulation, new legal regulations are needed. As a result of the changing country conditions, the Ministry of the Environment and Urbanization of Turkey prepared the draft regulation, published in 2017.

This study was conducted to scrutinise the existing and draft C\&D WM regulations in Turkey. Although the draft regulation was prepared to produce up-to-date solutions for C\&D WM in Turkey, there are some issues that the draft regulation still cannot answer. Deficiencies were revealed with this study and recommendations have been developed. It is thought that the regulation should come into force soon after the elimination of these deficiencies has been completed. It is assumed that the enactment of this regulation will be an important step in the prevention and reduction of $C \& D$ waste. It is considered that the amount of $C \& D$ waste resulting from refurbishment and demolition will be managed under proper conditions by entering this regulation into force so that environmental pollution will be reduced, and economic losses can be avoided. Furthermore, in order to ensure the proper implementation of the regulation, considerable effort and improvement are required in the communication and cooperation between government, local authorities and construction sector professionals. 


\section{Acknowledgement}

The author would like to acknowledge the valuable contributions of the anonymous reviewers regarding the improvements in the clarity and quality of this study. The author also

\section{References}

AECOM (Architecture, Engineering, Consulting, Operations, and Maintenance) (2018) "People's Republic of China: construction and demolition waste management and recycling", AECOM Asia Company Limited, Hong Kong, China, Rep. TA-8906 PRC.

Akıner, I., Akıner, E. (2009) "Evaluation of Turkish construction industry through the challenges and globalization", Organization, Technology and Management in Construction, 1(2), pp. 64-71. [online] Available at: https://hrcak.srce.hr/file/97373 [Accessed: 10 February 2019]

Birpınar, M. E., Akdağ Sarı, B. (2011) "Management of excavation soil and wreckage wastes in İstanbul", Sigma Journal of Engineering and Natural Sciences, 3(1), pp. 252-260. [online] Available at: http://eds. yildiz.edu.tr/sigma/ContentDetails?Volume $=3 \&$ IssueNumber $=1$ [Accessed: 10 February 2019]

Clark, C., Jambeck, J., Townsend, T. (2006) "A Review of Construction and Demolition Debris Regulations in the United States", Critical Reviews in Environmental Science and Technology, 36(2), pp. $141-186$

https://doi.org/10.1080/10643380500531197

Coşgun, N., Esin, T. (2006) "Türkiye’de Yapısal Atık Yönetim(sizlik) Sorunları" (C\&D Waste Management Problems in Turkey), In: Türkiye'de Çevre Kirlenmeleri Sempozyumu, Kocaeli, Turkey, pp. 19-24. (in Turkish)

DEFRA (Department for Environment, Food \& Rural Affairs) "UK statistics on waste", [pdf] Government Statistical Service, [online] Available at: https://assets.publishing.service.gov.uk/government/uploads/system/uploads/attachment_data/file/784263/ UK_Statistics_on_Waste_statistical_notice_March_2019_rev_ FINAL.pdf [Accessed: 20 June 2019]

Deloitte Turkey "Türkiye inşaat malzemeleri sektör görünüm raporu" (Turkey building materials sector outlook report), [pdf] Union of Chambers and Commodity Exchanges of Turkey, [online] Available at: https://www.tobb.org.tr/Documents/yayinlar/ Türkiye \%20İnşaat\%20Malzemeleri\%20Sektör\%20Görünüm\%20 Raporu.pdf [Accessed: 30 October 2018] (in Turkish)

EPD (Environmental Protection Department) "Monitoring of solid waste in Hong Kong-waste statistics for 2015", [pdf] EPD Available at: https://www.wastereduction.gov.hk/sites/default/files/msw2015. pdf [Accessed: 20 August 2018]

EUROSTAT (Statistical Office of the European Union) "Waste statistics", [online] Available at: https://ec.europa.eu/eurostat/statistics-explained/index.php?title=Waste_statistics\&oldid $=447576$ [Accessed: 11 March 2019]

MLIT (Ministry of Land, Infrastructure, Transport and Tourism) "White paper on land, infrastructure, transport and tourism in Japan", [pdf] MLIT Available at: http://www.mlit.go.jp/common/001063075.pdf [Accessed: 20 August 2018] would like to thank the students who attended "ARC505 C\&D Waste Management" course in 2017-2018 Academic Year Fall Semester at Erciyes University, Graduate School of Naturel and Applied Science, Architecture Program.

Official Gazette of the Republic of Turkey (1959) "Umumi Hayata Müessir Afetler Dolayısiyle Alınacak Tedbirlerle Yapılacak Yardımlara Dair Kanun" (Law Regarding Assistance and Precautions for Disasters Occurring in Public Life), Presidency of the Republic of Turkey Administrative Affairs General Directorate of Law and Legislation, Turkey. (in Turkish)

Official Gazette of the Republic of Turkey (1983) "Çevre Kanunu" (Environment Law), Presidency of the Republic of Turkey Administrative Affairs General Directorate of Law and Legislation, Turkey. (in Turkish)

Official Gazette of the Republic of Turkey (1988) "Afetlere İlişkin Acil Yardım Teşkilatı ve Planlama Esaslarına Dair Yönetmelik" (Regulation Regarding Immediate Support Organization and Planning Principles of Disasters), Presidency of the Republic of Turkey Administrative Affairs General Directorate of Law and Legislation, Turkey. (in Turkish)

Official Gazette of the Republic of Turkey (1991) "Katı Atıkların Kontrolü Yönetmeliği" (Regulation of the Control of Solid Wastes), Presidency of the Republic of Turkey Administrative Affairs General Directorate of Law and Legislation, Turkey. (in Turkish)

Official Gazette of the Republic of Turkey (2004a) "Hafriyat Toprağı, İnşaat ve Yıkıntı Atıklarının Kontrolü Yönetmeliği" (Regulation of the Control of Excavation Soil, and Construction and Demolition Waste), Presidency of the Republic of Turkey Administrative Affairs General Directorate of Law and Legislation, Turkey. (in Turkish)

Official Gazette of the Republic of Turkey (2004b) "Büyükşehir Belediyesi Kanunu" (Metropolitan Municipality Law), Presidency of the Republic of Turkey Administrative Affairs General Directorate of Law and Legislation, Turkey. (in Turkish)

Official Gazette of the Republic of Turkey (2005a) "Tehlikeli Atıkların Kontrolü Yönetmeliği" (Regulation of the Control of Hazardous Wastes), Presidency of the Republic of Turkey Administrative Affairs General Directorate of Law and Legislation, Turkey. (in Turkish)

Official Gazette of the Republic of Turkey (2005b) "Kabahatler Kanunu" (Misdemeanours Law), Presidency of the Republic of Turkey Administrative Affairs General Directorate of Law and Legislation, Turkey. (in Turkish)

Official Gazette of the Republic of Turkey (2010a) "Madencilik Faaliyetleri ile Bozulan Arazilerin Doğaya Yeniden Kazandırılması Yönetmeliği" (Regulation of the Reclamation of Lands Destroyed Resulting from Mining Activities), Presidency of the Republic of Turkey Administrative Affairs General Directorate of Law and Legislation, Turkey. (in Turkish)

Official Gazette of the Republic of Turkey (2010b) "Atıkların Düzenli Depolanmasına Dair Yönetmelik" (Regulation Pertaining to Regular Storage of Wastes), Presidency of the Republic of Turkey Administrative Affairs General Directorate of Law and Legislation, Turkey. (in Turkish) 
Official Gazette of the Republic of Turkey (2010c) "Bazı Tehlikeli Maddelerin, Müstahzarların ve Eşyaların Üretimine, Piyasaya Arzına ve Kullanımına İlişkin Kısıtlamalar Hakkında Yönetmelikte Değişiklik Yapılmasına Dair Yönetmelik"(Regulation of Amendments in the Regulation on the Restrictions for the Manufacture, Marketing and Use of Certain Dangerous Substances and Preparations), Presidency of the Republic of Turkey Administrative Affairs General Directorate of Law and Legislation, Turkey. (in Turkish)

Official Gazette of the Republic of Turkey (2014) "Orman Kanununun 16ncı Maddesinin Uygulama Yönetmeliği" (Regulation of the Implementation of Article 16 of the Forest Law), Presidency of the Republic of Turkey Administrative Affairs General Directorate of Law and Legislation, Turkey. (in Turkish)

Official Gazette of the Republic of Turkey (2015) "Atık Yönetimi Yönetmeliği" (Regulation of Waste Management), Presidency of the Republic of Turkey Administrative Affairs General Directorate of Law and Legislation, Turkey. (in Turkish)

Oxford Business Group "Turkey's construction sector to maintain its significant role in the economy, with several large projects under way", [online] Available at: https://oxfordbusinessgroup.com/turkey-2015 [Accessed: 30 October 2018]

Republic of Turkey Ministry of the Environment and Urbanization (2017) "Yıkım İşlemleri ile Hafriyat Toprağı, İnşaat ve Yıkıntı Atıklarının Kontrolü Yönetmelik Taslağı" (Draft Regulation for Demolition Operations and Controlling Excavation Soil, and Construction and Demolition Waste), Turkey. (in Turkish)
Salgın, B. (2009) "Türkiye’de yapısal atık yönetimi ile ilgili yasal düzenlemeler ve yetersizlikler" (Related legislation with construction and demolition waste management in Turkey and deficiencies), TOL, 7, pp. 89-94. (in Turkish)

Salgın, B., Coşgun, N. (2018) "Kentsel dönüşüm uygulamalarında yapısal atık sorunu ve çözüme yönelik öneriler: Kayseri örneği" (C\&D waste as a problem in urban transformation projects and recommendations for solution: Kayseri as a case study), Omer Halisdemir University Journal of Engineering Sciences, 7(1), pp. 465-476. (in Turkish)

https://doi.org/10.28948/ngumuh.387388

Townsend, T., Anshassi, M. "Benefits of construction and demolition debris recycling in the United States", [pdf] Construction and Demolition Recycling Association, Available at: https://cdrecycling.org/site/assets/files/1050/cdra_benefits_of_cd_recycling _ final_revised_2017.pdf [Accessed: 01 November 2018]

Tuna Taygun, G. (2016) "Kentsel dönüşümde asbest riski" (Risk of asbestos in urban transformation), Mimarlık, 390, pp. 78-81. [online] Available at: http://www.mimarlikdergisi.com/index. cfm?sayfa=mimarlik\&DergiSayi $=404 \&$ RecID $=3962 \quad$ [Accessed: 15 October 2018] (in Turkish)

Wang, J. Y., Kang, X. P., Tam, V. W. Y. (2008) "An investigation of construction wastes: an empirical study in Shenzhen", Journal of Engineering, Design and Technology, 6(3), pp. 227-236. https://doi.org/10.1108/17260530810918252 